\title{
Correlation between albumin creatinine ratio and hypertension in type
}

\section{2 diabetes}

\section{Korelasi antara albumin creatinine ratio dan hipertensi pada diabetes tipe 2}

\author{
Vitasari Indriani ${ }^{1{ }^{* *}, \text { Wahyu Siswandari }}{ }^{2}$, Pugud Samudro ${ }^{3}$, Nor Sri Inayati ${ }^{4}$ \\ Faculty of Medicine Jenderal Soedirman University Purwokerto, 53112, Indonesia \\ 11vita.indriani@gmail.com *; ${ }^{2}$ wahyu_swdr@yahoo.com; ${ }^{3}$ nurrinaa@gmail.com \\ * corresponding author
}

Tanggal Submisi: 1 Desember 2019, Tanggal Penerimaan: 1 Januari 2020

\begin{abstract}
Hypertension is often found in patients with type 2 diabetes. Albumin Creatinine Ratio (ACR) is used to detect early symptoms of kidney disease in patients with type 2 diabetes. The aim of this study is to determine the correlation between ACR and hypertension, as well as its relationship with other risk factors in type diabetes patients 2. Data were collected from 112 diabetic patients at PROLANIS FKTP Banyumas to see ACR and blood pressure. The results showed that poor glycemic control could be one of the risk factors. It can be concluded that detecting kidney dysfunction through ACR and starting treatment as early as possible can avoid the worst possibilities in type 2 diabetes patients.
\end{abstract}

Keywords: ACR; Hypertension; Type 2 Diabetes Mellitus

\begin{abstract}
Abstrak
Hipertensi sering ditemukan pada pasien diabetes tipe 2. Albumin Creatinine Ratio (ACR) digunakan untuk mendeteksi gejala awal penyakit ginjal pada pasien diabetes tipe 2. Tujuan dari penelitian ini adalah menentukan korelasi antara ACR dan hipertensi, juga hubungannya dengan faktor risiko lain pada pasien diabetes tipe 2. Data dikumpulkan dari 112 pasien diabetes di PROLANIS FKTP Banyumas untuk melihat ACR dan tekanan darah. Hasil penelitian menunjukkan bahwa kontrol glikemik yang buruk dapat menjadi salah satu faktor penyebab resiko. Dapat disimpulkan bahwa mendeteksi disfungsi ginjal melalui ACR dan memulai pengobatan sedini mungkin dapat menghindari kemungkinan terburuk pada pasien diabetes tipe 2 .
\end{abstract}

Kata kunci : ACR; Hipertensi; Diabetes Mellitus Tipe 2

\section{INTRODUCTION}

Diabetes Mellitus continue to become a massive issue for public health nowadays. The long-term detrimental effects of hyperglycemia especially on various end-organs requires regular monitoring especially on organ functions to prevent further impacts such as complications on behalf of diabetes. Diabetes mellitus relation is often associated with end-stage renal disease (ESRD) due to diabetic nephropathy. Early 
recognition of renal impairment can be investigated from the albumin creatinine ratio in random urine samples. Diabetes and Hypertension coexist. Hypertension in the diabetic individual can increases and accelerates the course of cardiac disease, stroke, peripheral vascular disease, retinopathy, and nephropathy. Before being detected with type 2 diabetes, patients may have had hypertension many years before. Furthermore, hypertension is also found in about $70-80 \%$ of patients diagnosed with type 2 diabetes mellitus. Along with this, further risk in patients due to increased blood pressure in diabetic nephropathy.

Diabetic nephropathy development is marked by a progressive increase in the excretion of protein, especially albumin. End-stage renal failure can also be an impact of an uncontrollable rise in systolic blood pressure, and a late decline in glomerular filtration rate. Systolic blood pressure may be particularly crucial as stated in the UKPDS (United Kingdom Prospective Diabetes Study), higher blood pressure was strongly associated with a higher risk of macro and microvascular disease.

Hypertension and albuminuria frequently coexist. This bound is strongly correlated with increased cardiovascular risk through a controversial mechanism. It is proven that coexisting hypertension worsens diabetic nephropathy. Furthermore, diabetic nephropathy somehow results in a markedly increased hypertension risk. The American Diabetes Association urged that type 2 diabetic patients be tested for albuminuria or albumin creatinine ratio in the earliest stage of diabetes and yearly thereafter. More severe renal involvement can be prevented by earlier screening and controlling blood pressure. Controlling blood pressure is indeed as important as controlling glucose, especially after the outbreak of renal damage. This study was conducted to see the correlation between albumin creatinine ratio and hypertension in type 2 diabetics, also its correlation with other risk factors.

\section{METHODS}

About one hundred and twelve types 2 diabetic patients who attended the Program Pengelolaan Penyakit Kronik (Prolanis) in FKTP Banyumas were contributed to this study. The patients' ages range from 30-70 years. This study was conducted in twelve months. Before taking the data, each patient gave informed consent. The data that taken from the questionnaire are including; the characteristic data such as gender, age, height and body weight (while wearing lightweight clothing and without shoes) also family health record of DM. Moreover, the data about blood pressure and smoking habit were also recorded for each patient. However, diabetic patients who suffering from co-morbidities like renal and liver diseases or chronic heart disease, as evidenced by either history of ischemic heart disease or ECG; renal disease or BUN creatinine disordered health record; liver disorder such as hepatitis B or C positive or liver function disorder tests were excluded from this study. The BMI data was taken by calculated weight $(\mathrm{Kg})$ divided by height $\left(\mathrm{m}^{2}\right)$. The data of blood pressure was measured with a suitable mercury sphygmomanometer. The data were taken by a physician after the patients had been resting comfortably with back supported in the sitting or supine position, for at least 5 minutes or at least 30 minutes after smoking or taking coffee. The blood pressure data was measured two times with 5 minutes interval. The systolic (SBP) and diastolic (DBP) measurements were taken through the 1st and the 5th Korotkoff sounds. The data used was the second blood pressure measurement of each individual. Systolic $+(2 x$ diastolic) pressure was the formula to calculate the mean arterial pressure (MAP). If systolic blood pressure (SBP) $\geq 140 \mathrm{mmhg}$ and/ or diastolic 
blood pressure (DBP) of $\geq 90 \mathrm{mmhg}$ or use of anti-hypertensive medications it is considered as high blood pressure. 7 Blood samples were taken for the $\mathrm{HbA} 1 \mathrm{c}$ test that was estimated by using a chromatography method. All measurements were performed under the instructions of the manufacturers. HbAlc data was taken from the mean of three consecutive Hbalc levels, either $<6.5 \%$ or $\geq 6.5 \%$. A morning mid-stream urine sample was used to calculate albumin and creatinine ratio by considering immunoturbidimetric and calorimetric methods. Association between outcome variables and independent variables were measured by using T-Test.

\section{RESULTS AND DISCUSSIONS}

Patients were divided into two groups based on the difference in blood pressure. Group 1 is called a group of diabetic patients with hypertension: $(n=45)$ and the second group consisting of diabetic patients without hypertension $(n=67)$. Both groups were assessed for systolic (SBP), diastolic (DBP) and mean arterial pressure (MAP).

Table 1. Characteristics of both groups

\begin{tabular}{lccc}
\hline \multicolumn{1}{c}{ Variables } & \multicolumn{1}{c}{ Group } & \\
\cline { 2 - 4 } Gender: & Group 1(n=45) & Group 2 (n=67) & \\
Male (35) & & & \\
Female (53) & 10 & 25 & \\
Age (years) & 35 & 42 & \\
\hline Family History of DM: & $59.89 \pm 9.34$ & $48.4 \pm 8.32$ & \\
Positive & 32 & 47 & \\
Negative & 13 & 20 & 0.678 \\
BMI & $28.90 \pm 4.17$ & $28.61 \pm 4.09$ & $<0.001$ \\
HbA1c(\%) & $7.31 \pm 1.59$ & $7.72 \pm 0.807$ & $<0.001$ \\
ACR (mg/g) & $168 \pm 23$ & $35.98 \pm 15$ & \\
\hline
\end{tabular}

Group 1 showed a higher Albumin Creatinine Ratio (ACR) compared to group 2 as evidenced by $\mathrm{p}<.001)$. However, group 2 showed a higher HbAlc value as compared to group1.

Table 2. The blood pressure differences between two groups

\begin{tabular}{cccc}
\hline \multirow{2}{*}{ Variables } & \multicolumn{3}{c}{ Group } \\
\cline { 2 - 4 } & Group 1 & Group 2 & P-Value \\
\hline SBP & $133.4 \pm 15.92$ & $110.12 \pm 5.47$ & $<0.001$ \\
DBP & $94.54 \pm 7.77$ & $80.20 \pm 3.95$ & $<0.001$ \\
Mean & $102.86 \pm 10.12$ & $112.89 \pm 3.69$ & $<0.001$ \\
\hline
\end{tabular}

Based on the data above, the SBP and DBP level in group 1 is higher than in Group 2. It can be concluded that diabetic patients with hypertension have a higher risk of renal function complication comparing to patients with hypertension seen from the higher SBP and DBP.

Our study proved a significant statistical correlation between hypertension and microalbuminuria; this finding was also strongly correlated with poor glycemic control. This study also showed that hypertension can cause microalbuminuria and hypertensive nephropathy that can be an accelerating factor of diabetic nephropathy progression. In line with that, hypertension can be a cause and an effect of diabetic nephropathy. Epidemiological studies have shown that overt nephropathy can be prevented by 
identifying, monitoring, and giving treatments to patients with microalbuminuria. The values of Systolic blood pressure and diastolic blood pressure in patients with microalbuminuria are higher than in normoalbuminuric patients. It can be concluded that hypertension is strongly correlated with microalbuminuria. This study was conducted in line with the fact that in the past few years, the occurrence of diabetes mellitus has been increased throughout the world. Moreover, this is strongly correlated with the increase of cardiovascular diseases which also impact morbidity and mortality seen in patients with diabetes. The high predominance of microvascular complications in diabetes such as diabetic nephropathy shows that the number of patients with endstage renal disorder due to diabetes will also increase dramatically. Hence, renal replacement therapy is started due to diabetes, especially type 2 diabetes. The United Kingdom prospective diabetes study (UKPDS), a well-known study focusing on diabetes mellitus stated that the presence of hypertension is a risk factor for microalbuminuria and retinopathy; furthermore, it is reducing the incidence of chronic complications that was significantly associated with the amplitude of systolic blood pressure decrease, the lowest risk corresponding to a systolic blood pressure below 120 mmHg. 4 The risk factors that correlated with microalbuminuria were found to be poor glycemic control and hypertension. It is now broadly accepted that the excretion of even small amounts of albumin in the urine may augur serious future case, such as elevation of systemic arterial pressure, cardiovascular disorder and progressive renal dysfunction Primarily, microalbuminuria is a sensitive sign for damage caused by diabetes. The combination of hypertension and diabetes is a tremendously dangerous clinical case, due to the risk of macro and microvascular complications of diabetes, diabetes-related disease and overall, mortality. Hypertension is somehow coexisting in patients with diabetes. Unfortunately, hypertension occurs in $50 \%$ of patients with diabetes and results in an increase in mortality. Coexistent of nephropathy in patients with diabetes and hypertension resulting in a 37-fold increase in mortality. Diabetic nephropathy and hypertension are probably interplaying each other, both as cause and effects. Studies have proved an association between microalbuminuria and high levels of blood pressure. Ahmedani et al. in his study stated that microalbuminuria positive group had a higher systolic and diastolic blood pressure compared to microalbuminuria negative group ( $\mathrm{p}<0.001)$ which has been observed by others. In line with that, Lehman, et al (2009) and Mihardja, et al(2014) also reported a good statistical correlation between the prevalence of microalbuminuria and the diastolic blood pressure. Furthermore, in his study, Muslim et al found that microalbuminuric patients had a higher level of systolic and diastolic blood pressure, it can be concluded that systolic blood pressure is a significant risk factor for diabetic nephropathy. Besides, Mutmainah et al. proved that high blood pressure increased the risk of developing signs of nephropathy.

\section{CONCLUSIONS}

High prevalence of ACR is in line with hypertension in diabetic type 2 patients. ACR could be an early sign of diabetes, so that screening for microalbuminuria is necessary for the prevention of further complications such as end-stage renal disease and cardiovascular disease. Thus, physicians should strictly monitor all subjects and regularly measure the $\mathrm{HbA} 1 \mathrm{C}$ level. Patients should also be informed about lifestyle including weight control, alcohol cessation, and other regular activities. 


\section{REFERENCES}

American College of Cardiology. (2017). Guideline for the Prevention, Detection, Evaluation, and Management of High Blood Pressure in Adults. Clinical Practice Guidelines. 1(1): 4-28

American Diabetes Association. (2018). Standards of Medical Care in Diabetes. Diabetes Care. 33 (1) : 11-4.

Audehm, R., Arthur, I., Barlow, J., Kennedy, M., Kilov, G., Leow, S., et al. (2014). General Practice Management of Type 2 Diabetes. The Royal Australian College of General Practitioners and Diabetes Australian . pp :47-51.

Bawazier LA. (2014). Proteinuria dalam Buku Ajar Ilmu Penyakit Dalam. Edisi VI. Jakarta: IPD FK UI. hlm: 956.

Carey, R.M. (2007). Hypertension and Hormone Mechanisms. Humana Press. Totowa. New Jersey.

Cho, N. H. et al. High Blood Pressure and Its Association With Incident Diabetes Over 10 Years in the Korean Genome and Epidemiology Study (KoGES). Diabetes Care 38, 1333-1338, https://doi.org/10.2337/dc14-1931 (2015).

Dennison-himmelfarb C., Handler J. and Lackland D.T. (2014). Evidence Based Guideline for the Management of High Blood Pressure in Adults Report From the Panel Members Appointed to the Eighth Joint National Committee (JNC 8). American Medical Assosiation. 1097. 1-14.

Dutta, D., Choudhuri, S., Mondal, S. A., Mukherjee, S. \& Chowdhury, S. Urinary albumin: creatinine ratio predicts prediabetes progression to diabetes and reversal to normoglycemia: role of associated insulin resistance, infammatory cytokines and low vitamin D. $J$ Diabetes 6, 316-322, https://doi.org/10.1111/1753-0407.12112 (2014).

Fatimah, Restyana Noor. 2015. Diabetes Melitus Tipe 2. J Majority. 4(5) hal. 93-101.

Garnita, D. (2012). Faktor Risiko Diabetes Melitus di Indonesia Analisa Data Sukerti 2007. Skripsi. Depok : FKM UI.

Guyton, A.C., Hall, J.E. (2008). Buku Ajar Fisiologi Kedokteran. Jakarta: EGC.

Hakim, Buraerah H., Abdullah, A. Zulkifli, Hanis, M. (2010). Analisis Faktor Risiko Diabetes Melitus Tipe 2 di Puskesmas Tanrutedong, Sidenreng Rappang, 2007. Jurnal Kedokteran Indonesia, 35 (4).

Hendromartono. (2014). Nefropati Diabetik. Buku Ajar Ilmu Penyakit Dalam. Edisi VI Jilid II. Jakarta: Pusat Penerbit FKUI. hlm :2386-396

International Diabetes Federation (IDF). (2017). Clinical Practice Recommendations for Managing Type 2 Diabetes in Primary Care. Jurnal online [diunduh 2 April 2018]. Tersedia dari: http://www.idf.org.

Joshi KR, Ashish G, Dipendra RP, Keshab P. (2013). Serum Creatinine and Urine Microalbumin Level in Hypertensive and Non hypertensive Patients. Medical Journal of Shree Birendra Hospital. 12: 27-29.

Kara, A. (2012). Renal Function. Clinical chemistry 6th ed. Philadephia: Wolters Kluwer.

Koubaa, A., Sriha BA., Harzallah N., Bellaleh A., Sahtout M., Younes K., et al. (2016). Screening for Nephropathy in Diabetes Melitus: Is Micral-Test Valid among All Diabetics?. International Journal of Chronic Diseases.

Lehman R, Krumholz HM. (2009). Tight control of blood glucose in long standing type 2 diabetes. BMJ. pp :338-800. 
Mihardja L, Soetrisno U, Soegondo S. (2014). Prevalence And Clinical Profile Of Diabetes melitus In Productive Aged Urban Indonesians. J Diabetes Invest. (5) :507-512.

Muslim, A. (2014). Jumlah Leukosit dengan Kadar Mikroalbumin Urin Penderita Diabetes Melitus. Jurnal Kesehatan. 1 (1): 40-43.

Mutmainah, I. (2013). Hubungan Kadar Gula Darah dengan Hipertensi pada Pasien Diabetes melitus Tipe 2 di Rumah Sakit Umum Daerah Karanganyar. Karanganyar.

Paputungan, S.R., Sanusi, H. (2014). Peranan Pemeriksaan Hemoglobin A1c pada Pengelolaan Diabetes Melitus. CDK-220. 41(9): 650-655.

Pilz, S. et al. Insulin sensitivity and albuminuria: the RISC study. Diabetes Care 37, 1597-1603, https://doi.org/10.2337/dc13-2573 (2014)

Welsh, G. I. \& Coward, R. J. Podocytes, glucose and insulin. Current opinion in nephrology and hypertension 19, 379-384, https://doi. org/10.1097/MNH.0b013e32833ad5e4 (2010) 